\title{
コリン仮説とアミロイド仮説による アルツハイマー病治療薬開発の新アプローチ
}

要約：世界で始めてアルツハイマー病の治療薬として 承認されたものはコリン仮設に基づくものであった, すなわちアセチルコリンエステラーゼ (AChE) 阻害 薬である。その後の研究から $\mathrm{AChE}$ 阻害薬は神経保 護作用やアルッハイマー病 $(\mathrm{AD})$ の原因と考えられ ている $\beta$ アミロイドの産生を抑制することが示されて いる．仮にこれらの作用が MCI（Mild Cognitive Impairment）に対して効果が示されれば，AChE 阻害薬 の新たな方向が見出されることになる．最近，選択的 なブチリルコリン（BChE）阻害薬はアセチルコリン (ACh) を増加すること，また $\beta$ アミロイドの産生を 抑制する作用が報告された。さらなる研究が必要では あるがコリン仮説の別な視点での治療薬に繋がる可能 性が示されれば大変興味ある知見となる。しかし現在 の $\mathrm{AD}$ の原因に迫る治療薬としてはアミロイド仮説に 基づくものが最も有力である。 $\beta$ アミロイドを産生す
る䤉素は APP と呼ばれる前駆タンパク質から $\beta$ アミ ロイドを切り出してくる，その酵素は $\alpha$ セクレターゼ,

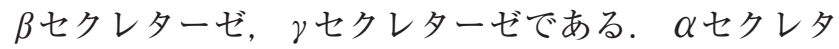
一ゼは $\beta$ アミロイドそのもを切断する酵素であり，こ の場合は活性化するものが $\beta$ と $\gamma$ のクレターゼは阻 害薬が望むものとなる．この考えかたに基づく方法は アミロイド仮説と呼ばれるものだが，すでに臨床試験 に入っている化合物がある。近い将来 $\mathrm{AD}$ を原因から 治す薬が開発されることも夢ではない.

\section{1．アセチルコリンエステラーゼ阻害薬}

今, $\mathrm{AD}$ として承認された治療薬は世界に5つある。 $\mathrm{AChE}$ 阻害作用に基づくもので，タクリン，ドネペジ ル，リバスチグミンそしてガランタミンの 4 つと, NMDA 拮抗作用に基づくメマンチンである（図 1). $\mathrm{AChE}$ 阻害作用に基づく創薬のアプローチは 1970 年

アセチルコリンエステラーゼ（AChE）阻害薬

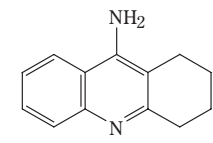

Tacrine
(Warner-Lambert)

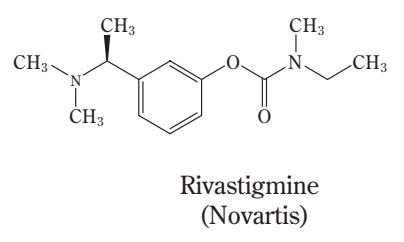

図 1 アルツハイマー病治療薬
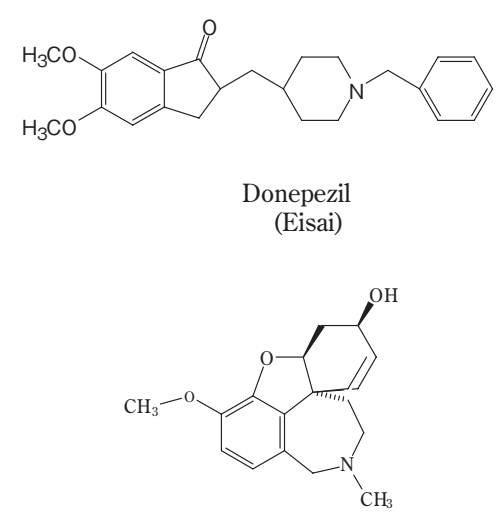

Galanthamine (Waldheim Pharm.)
NMDA 受容体拮抗薬

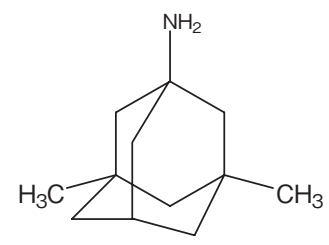

Memantine(Lundbeck)

キーワード：アルツハイマー病, コリン仮説, ドネペジル, ブチリルコリンエステラーゼ, $\beta$ アミロイド仮説 京都大学大学院薬学研究科（干606-8501 京都市左京区吉田下阿達町 46-29） e-mail: hsugimot@pharm.kyoto-u.ac.jp＼cjkstart原稿受領日：2008 年 1 月 18 日，依頼原稿

Title: New approaches for the development of anti-Alzheimer's disease drugs based on the cholinergic hypothesis and amyloid hypothesis. Author: Hachiro Sugimoto 

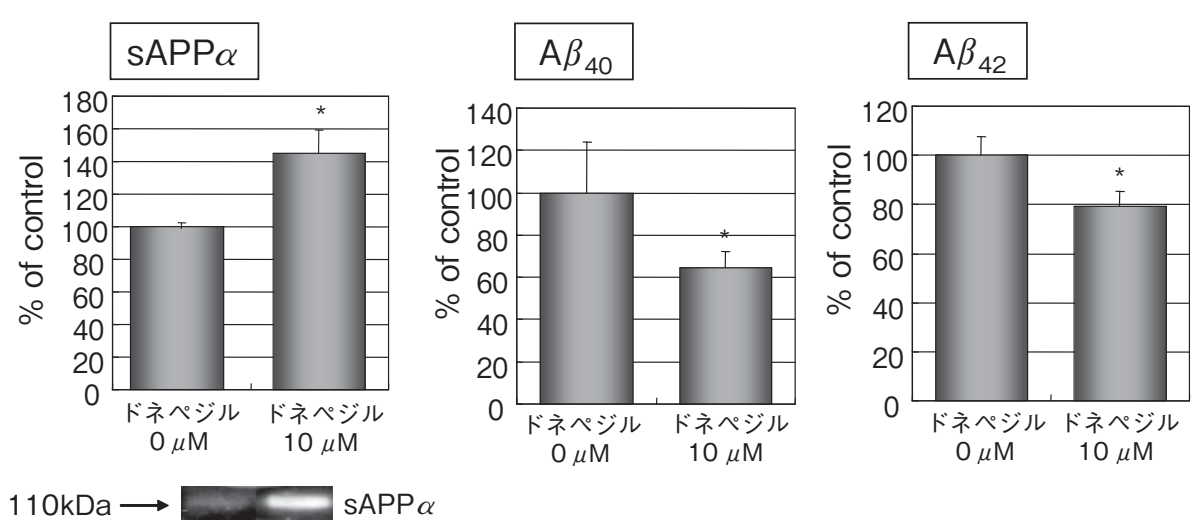

図 2 ドネペジルの $\beta$ アミロイド産生抑制効果

*: P< 0.05 vs ドネペジル $10 \mu \mathrm{M}$, Student's t-test. (Nishimoto T, et al. Neuroscience. 2005;Nov.)

代に Davies や Perry らが発表した論文 $(1 ， 2)$ によ るものである。彼らは $\mathrm{AD}$ の患者の脳を調べた結果, アセチルコリン作動性神経が障害を受けていることを 発見した。これは神経伝達物質の一種である AChが 減少していることを意味している。 それゆえ記憶を改 善するには脳内の ACh を増加すればよいのではない かという, コリン仮説が生まれた。

最近, これらの AChE 阻害薬が神経細胞の保護作 用を示すことがわかった。赤祖父らは虚血条件下にお いてドネペジルは細胞保護作用を示すことを発表した (3).また高田らはドネペジル, タクリン, リバスチ グミン，ガランタミンなどの AChE 阻害薬がグル夕 ミン酸の神経毒性に対して保護作用があることを示し た論文を発表した (4). 高田らはこのグルタミン酸の 神経毒性の保護作用はニコチン受容体を介して示され ることを解明している。

また当研究室の西本らはドネペジルは $\beta$ アミロイド の神経毒性に対しても保護作用を示すことを見出した. このドネペジルの $\beta$ アミロイドの神経保護作用はニコ チン受容体を介したものであると推定している. しか し $\beta$ アミロイドの毒性保護効果の $\mathrm{IC}_{50}$ は $10 \mu \mathrm{M}$ とい う比較的高い濃度であるので, 生理的な条件での効果 を望むことは難しい（図 2).

最近, 臨床で注目されていることは Mild Cognitive Impairment (MCI, 軽度認知機能障害) に対する研 究がある.しかし $\mathrm{AD}$ の診断基準は長谷川式評価法, ADAS- cog や MMSE という一定の基準は作られてい るが，MCIについての診断基準は必ずしも確定して いるとは思えない. 最近, Ronald C. Petersenは次の ような基準を提唱している (5).すなわち 1) 第三者 から見て記憶障害があること，2）加齢から来る記憶 障害は認められる，3）一般的な認知機能は保持され
ていること,4)日常生活はほぼ正常に保たれている, 5) いわゆる認知症ではない，少し分かりにくい定義であ るが，MCI 自体が病気という定義に入らないことを 考えると現状ではこの程度の基準であろう。いま世界 的な規模で診断基準をしっかり決める方向で検討され ているが，その背景には MCIになった場合にかなり の割合で $\mathrm{AD}$ に移行するというデータがある。また $\mathrm{AD}$ になってしまっては脳細胞がかなりダメージを受 けていることから， $\mathrm{AD}$ の前段階である $\mathrm{MCI}$ から治 療の対象にすれば，より多くのヒトが $\mathrm{AD}$ にならない で救われるかも知れないということがある. 先ほどの Ronald C. Petersen らの臨床試験の結果では MCI に対 してドネペジルの効果が期待がもてるかもしれない, という報告がある（6）。

\section{2. ブチリルコリンエステラーゼ阻害薬}

今までコリン仮説の中では全く評価されていなかっ たブチリルコリンエステラーゼ阻害薬の薬理効果につ いていくつか報告がなされている. Nigel H. Greig ら は phenserine の誘導体である cymserine が AChE よ りブチリルコリンエスレラーゼ（BChE）により強く 阻害作用を示すことを報告している $(7)$. さらに cymserine の誘導体である PEC と BNC はわずかな構 造変換で数千倍の $\mathrm{BChE}$ へ選択性の高い化合物を 得ている（図 3)。さらにPEC 化合物はラットの大脳 皮質において容量依存的 ACh を増加作用を示した. またこれらのPEC はトランスジェニックマウスの脳 内の $\beta$ アミロイド 40 と 42 を有意に減少させたデー夕 を示した. PEC 化合物が $\beta$ アミロイドを減少させる メカニズムは明確ではない.また BChE 阻害作用と $\beta$ アミロイドを減少させる関係についても明らかでは ない.しかし physostigmine を出発として phenserine 
<smiles>[R7]N1CC[C@]2(C)c3cc(OC(=O)Nc4ccc(C(C)C)cc4)ccc3N([R7])[C@H]12</smiles>

Chemical structure of cymserine analogs

Cymserine: $\mathrm{R}_{1}=\mathrm{CH}_{3}, \quad \mathrm{R}_{2}=\mathrm{CH}_{3}$ $\mathrm{AChE} / \mathrm{BChE}$

15

BNC:

$\mathrm{R}_{1}=\mathrm{H}, \quad \mathrm{R}_{2}=\mathrm{H}$

$\mathrm{AChE} / \mathrm{BChE}>5000$

PEC:

$\mathrm{R}_{1}=\mathrm{PhCH}_{2} \mathrm{CH}_{2^{-}}, \mathrm{R}_{2}=\mathrm{CH}_{3} \mathrm{AChE} / \mathrm{BChE}$

110

図 3 Cymserine とその誘導体の BChE に対する選択性

(Nigel H Greig, et al. PNAS 2005;102:17213-17218.)

が誘導せれた。ここまでは $\mathrm{AChE} に$ 選択的であるが わずかに構造を変換させただけで BChE 阻害作用を 示す化合物を発見したことは興味あることである.

$\mathrm{BChE}$ 阻害薬は新しい $\mathrm{AD}$ 治療薬の可能性を展開でき るかも知れない.

\section{3. $\beta$ アミロイド仮説}

$\beta$ アミロイド 40 または 42 が前駆タンパク質である Amyloid Precursor Protein (APP) からセクレターゼ によって切り出される. その $\beta$ アミロイド 40 または 42 が脳内で凝集し老人斑（amyloid plaque）が形成さ れる.この老人斑が形成される過程にできる $\beta$ アミロ イドのオリゴマーが神経毒性を示し, 神経細胞が脱落 する．この一連のカスケードをアミロイド仮説と呼ば れていて, 現在では $\mathrm{AD}$ の発症の主原因であると考え られている(8).

アミロイドの産生は APP のベータサイトを $\beta$ - セク レターゼが切断し, ついで $\gamma$-セクレターゼが切断す ることによって $\beta$ アミロイドが産生する。この仮説か ら考えられる創薬のアプローチは $\beta$ セクレターゼを阻 害するか, $\gamma$-セクレターゼを阻害すれば $\beta$ アミロイ ドの産生は抑制できる。また $\alpha$ サイトを $\alpha$ セクレタ 一ゼが切断した場合は $\beta$ アミロイドの途中から切断さ
れるために $\beta$ アミロイドは産生されない。それゆえ $\alpha$ セクレターゼの場合はこの酵素の活性を高めるこ とによって目的である $\beta$ セクレターゼの産生を抑制で きることになる.

アミロイド仮説に基づいてまた別な方法で $\mathrm{AD}$ の治 療薬の開発が試みられている。例えば $\beta$ アミロイドの 凝集過程に生成するオリゴマーが神経毒性を示すので あれば凝集を抑制する薬凨の開発 (9)(例として医薬 品としては成功していないが tramiprosate がある), 凝集してできた老人斑を分解するネプリライシンなど が発見された。米国の Elan 社が研究開発を進めてい た $\beta$ アミロイドのワクチン製剤などもある (10). 残 念ながらこのワクチンは臨床第二相試験で副作用が見 られたために開発は中止された。 しかしその後抗体製 剤に変えて臨床第三相試験に入る予定と言われている。

私たちが塩酸ドネペジルの開発研究を始めたころは $\mathrm{AD}$ の治療薬の創薬研究は極めて稀であった。 そのこ ろは脳血管障害改善薬と称して脳の血流を改善する方 法や脳血流を改善することにより脳機能, もしくは認 知症を改善することが研究の主流であった。その後 20 年, 今は $\mathrm{AD}$ の根本治療薬の開発も夢ではないと ころまで来ている，世界と日本の大手製薬企業はすで に $\beta$ アミロイド仮説に基づいた創薬研究の成果として 臨床試験を実施しているという。近い将来 $\mathrm{AD}$ の根本 治療薬に繋がる優れた薬が開発されることを切に祈る ものである.

\section{文献}

1) Davies P, et al. Lancet. 1976;2:1403.

2) Perry EK, et al. Lancet. 1977;1:189-191.

3) Akasofu S, et al. Eur J Pharmacol. 2003;472:57-63.

4) Takada Y, et al. J Pharmacol Exp Ther. 2003;306:772-777.

5) Petersen RC, et al. J Intern Med. 2004;256:183-194.

6) Petersen RC, et al. J Arch Neurol. 2004;61:1852-1856.

7) Greig NH, et al. Prog Natl Acad Sci. 2005;102:17213-17218.

8) Hardy J, et al. Science. 2002;297:353-356.

9) Aisen PS, et al. Neurology. 2006;67:1757-1763.

10) Schenk D, et al. Nature. 1999;400:173-177.

\section{著者プロフィール}

\section{杉本 八郎（すぎもとはちろう）}

京都大学大学院薬学研究科, 客員教授.

$\diamond 1961$ 年エーザイ(株)に入社. ’69 年中央大学理工学部 II 部卒業. ’8 2 年筑波研究所化学系主任研究員. ’95 年理事・筑 波研究所副所長を務める. '96 年広島大学医学部総合薬学研究科にて学位取得. ’ 02 年より創薬第一研究所理事所長. ’03 年退職, 同年 4 月より現職. ’ 05 年より中央大学理工学部客員教授. 同年中央大学理工学より名誉博士号授与される. 趣味は剣道（7段）と俳句. 